\title{
The Cultural Beginnings of the Lydo-Greek Interactions
}

\author{
M. Negmeldin ${ }^{\mathrm{a}}$, S. El-Hewaily ${ }^{\mathrm{b}}$ and A. Elnaggar ${ }^{\mathrm{c}}$
}

\section{Introduction}

Anatolia is always a pleasant residence to the migration movements of the Greek inhabitants, and its location formed the main corridor for transmission of ideas and peoples from Europe and the Near East. These cultural interactions may reach its climax in the transitional period between the Bronze Age and the Iron Age. In the following results of the Mycenaean collapse about the $12^{\text {th }}$ century B.C., the Greek craftsmen, artists, and traders left their homeland to retrieve activities through being settled in western Anatolian cities, such as Miletus, where it is found large quantity of locally-produced, non-Mycenaean imitation pottery, fortified remains, besides tomb types which assembled mixed features with Mycenaean and Hittite origins. Therefore, it can be distinguished four main areas in Anatolia, whose cultures had a profound influence on the eastern Greeks (Özgen, 1985):

1.1. The "Neo-Hittite Kingdoms" in the southeast of Anatolia, whose history and arts are known from Assyrian, some local sources, and relief sculptures. Its most important sites are Malatya, Carchemish, Zincirli, Maraš and some sites in the Tabal area. Most of the sculptures were executed before or in the $8^{\text {th }}$ century B.C., but were still visible in the $7^{\text {th }}$ century B.C.

1.2. Cilicia (i.e. Que), the site of Karatepe, with its series of sculptured orthostats, could be the best source for the study of its costume by the Iron Age.

1. 3/4. The kingdoms of Phrygia and Lydia in central and western Anatolia.

According to Herodotus (1.28), the Lydian kingdom had subdued all the people of western Anatolia except for Lycians and Cilicians. It is thought that the subjects of Lydia included artists of Phrygia, Mysia, Caria, and Greek, all working at Ephesus and influencing one another (Şare, 2010). Thus, the effective Anatolian interaction with Greek is clearly existed at least by the $8^{\text {th }}-7^{\text {th }}$ centuries B.C.,

\footnotetext{
${ }^{a}$ Professor Mohsen Negmeldin, Cairo University, Faculty of Archaeology.

${ }^{b}$ Professor Soliman El-Hewaily, Cairo University, Faculty of Archaeology. ${ }^{\mathrm{c}}$ Ahmed Abdel-maksoud Elnaggar, Teaching Assistant, Cairo University, Faculty of Archaeology; e-mail: nagger_17@yahoo.com; a.elnaggar@cu.edu.eg.
} 
whereas the western Anatolian people, all of Carians, Lycians, Phrygians and Lydians, is described in Iliad by fighting with Trojan army (van Dongen, 2013).

[Croesus afterwards, in the course of many years, brought under his sway almost all the nations to the west of the Halys. The Lycians and Cilicians alone continued free; all the other tribes he reduced and held in subjection. They were the following: the Lydians, Phrygians, Mysians, Mariandynians, Chalybians, Paphlagonians, Thynian and Bithynian Thracians, Carians, Ionians, Dorians, Aeolians and Pamphylians (Herodotus, 2014)].

In addition, the East Greek Art could be attributed to the Greeks who had settled on the western coast of Anatolia and the offshore islands. Although this area is linguistically and historically divided into three main regions, Aeolis in the north, Ionia in the middle and the Dorian group in the south, however its art is more conveniently treated as a whole, since the regional differences of the dialects are not always matched by artistic differences. The most important archaic sites in the East Greek region are the Samian Heraion, Ephesian Artemision and Miletos with Didyma (Özgen, 1985). In this article, we would focus on the early Greek history and pursuing their people who had an effective impact on the cultures of western Anatolian and their artificial spots, especially toward the kingdom of Lydia.

\section{The Early Greek Activities:}

Historically, the earliest Greeks can be pursued to the Minoan civilization of Crete (ca. 2800-1400 B.C.), who settled on the western shores. Its kings, known as the legendary Minos, created a civilization based on seaborne commerce between the Aegean and the Near East. The volcanic explosion which destroyed the island of Thera, lies 60 miles north of Crete, has been blamed for the end of Minoan civilization (Map 1). This catastrophe probably took place about 1650 B.C., being also remembered in the legend of Atlantis destruction (Markot, 1996). This would have led to a great economic downfall and most of surrounding countries seized an opportunity to strike against a prominent trading route. By 1600 B.C., the Greeks on mainland, called Achaeans or Mycenaeans, had learned the higher Minoan arts. They aggressively extended their trade to the western shores of Anatolia, known later as Ionia, establishing a colony at Miletus. Then, they conquered the Minoan capital of Knossos, about 1400 B.C., to be rebuilt and came under the Mycaneans sway. Then, this culture had a dramatic collapse; in which all palaces (except Athens) were sacked and burned (Harl, 2001). Little is known about the culture of western Anatolia during the Late Bronze Age that could be found among the 
cultural elements of Hittites; however, there is still no proof that any Hittite ever met the Mycenaeans in person (van Dongen, 2007). 


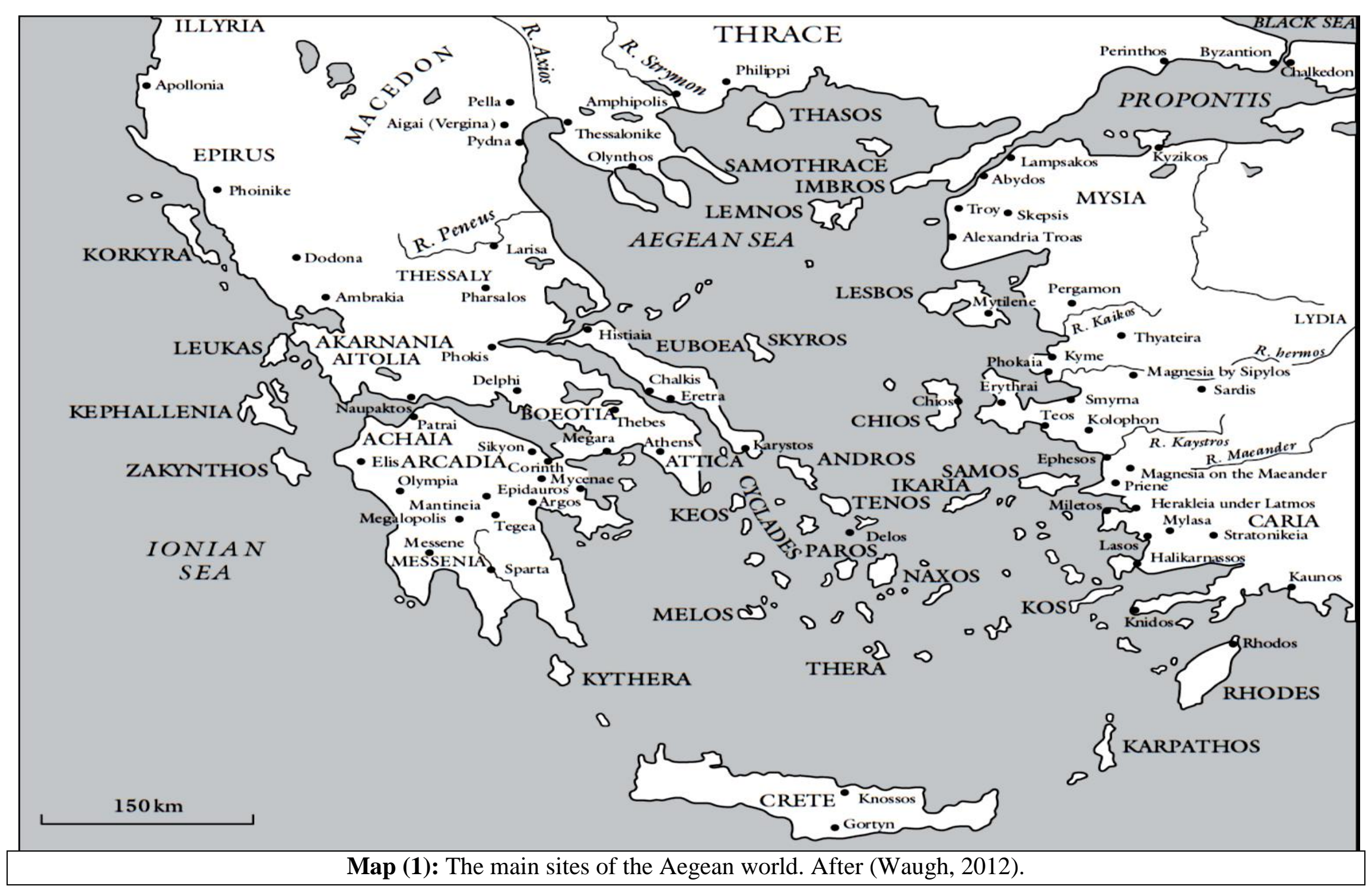


As probable result to the trading collapse in the Mycenaean settlements, villages from mainland and Aegean islands migrated throughout the eastern Mediterranean coast-line, including the region of Anatolia, where they were known as the "Sea Peoples", who attacked the Egyptian Empire towards the end of Late Bronze Age (Harl, 2001). There is supporting evidence on Chios and Rhodes and this event led to an increase of Greek settlements outside of the Aegean. Soon after 1200 B.C., with the fall of the Mycenaean system, Greek entered a period of shortage data, known as the Dark Ages (ca. 1225/1200-750 B.C., recently 1050-900 B.C.), that ends with the rise of the Greek city-states (Solano, 2015; van Dongen, 2008).

The archaeological evidence could have revealed that the people left their old centers after the palaces destruction; perhaps formed larger communities; but there is little evidence for contacts between the Greeks and the outside world during this period. Herein, Bryce (1999) postulated that the immigration of skilled craftsmen and itinerant in the Bronze Age was the most important agents of the east-west transmission. Literally, the Trojan War, the last great enterprise of the Greek heroes are situated near the end of the Late Bronze Age, but elements from that period have been mixed up with elements from later periods, to can be dated to the $8^{\text {th }}$ century B.C. (van Dongen, 2007).

\section{The Hellenizing of Western Anatolia:}

The resumption of Greek activities abroad and the rapidly growing role of the eastern Mediterranean trade could be clearly observed at the beginning of the Archaic Age (ca. 800-500 B.C.); in which the Greeks had already settled in the Aegean, Crete, western Anatolia and Cyprus, besides the continuous founding of colonies, all over the Mediterranean. Despite the spread of their cultural unity, it cannot easily be postulated for this period (van Dongen, 2007). Thus, the ancestral Greeks, who are remarkable by orderly architecture and speaking one of several prevailing dialects, could have been classified into major tribes of the Achaeans (Greeks), Dorians, Aeolians, and Ionians. Generally, it can be highlighted on the most immigrants that reached western Anatolia after the Trojan War (Waldman and Mason 2006), as follows:

3.1. Aeolians: They were the western neighbours of Lydians since the end of the $11^{\text {th }}$ century B.C. when immigrants from the Greek mainland had established on the Aegean Coast. They found a chain of settlements along the west coast and offshores islands (Kerschner, 2010). Their origins is still unknown, however, it 
seems that most of them had migrated eastward across the Aegean Sea to settle in Lesbos island and the northwest coast of Anatolia to the Hermos River in the south. The Aeolian architectural assemblage can illustrate their effective presence in northern part of the west Anatolian coast in about 600-550 B.C. (Jenkins, 2006).

3.2. Dorians: Both the migrating barbarians of Dorian Greeks and the Phrygians started in the south-east of Balkans, and overthrew the Achaean Greek and the Hittites after the collapse of the Mycenaean world. They were the northernmost of the four major Greek tribes which broke into peninsula and sacked the Achaean strongholds; then took to the sea and meted out the same treatment in Crete and Rhodes (Tomas, 1978).

3.3. Ionians: This migration has found its refuge from the Greek peninsula to the western Anatolian coast that was dotted with the Greek settlements, to be known as "Ionia" (Fontenrose, 1988). They could be a branch of the Dorian migration which swept away the Mycenaean and Minoan civilizations to be acknowledged as Peloponnese conquerors (ca. 1100-1000 B.C.). Thucydides (1.12.3-4) refers to their attendant after the Trojan War. According to both of Solon and Pherekydes, once the Ionians fled from the north of Peloponnese and the Dorian invasions, they first moved to Athens and the central coast of western Anatolia (Köse, 2012). Thus, they may reinstate the Mycenaean presence, Ahhiyawa of Hittite texts, around 1000 B.C. In addition, the Ionians had established on Aegean Coast and found a chain of settlements along the western coast to be the neighbours of Lydians since the end of the $11^{\text {th }}$ century B.C. (Kerschner, 2010). However, they did not establish a coherent political entity, but just a loose confederation of 12 independent city-states, extended from Miletus to Ephesus, nearby the islands of Chios and Samos. Their borders were bordered by Aeolian minor centers in the north (i.e. Lesbos) and the Doric ones in the south (i.e. Rhodes). Overall, this league never acted as an effective military alliance, even in the face of the Lydian or Persian campaigns (Liverani, 2014).

\section{The Lydian Activities towards the East Greek Cities:}

The advancement of Lydia started soon after Gyges had seized the throne and founded the Mermnads dynasty around 680 B.C. This period saw the rapid rise from a medium-scale regional kingdom to the supreme power in western Anatolia. A series of military assaults was waged on Ionian cities, starting with Gyges, who attacked Smyrna, colophon, and Miletus; also there exist statements about Gyges 
by Greek poets from Archilochos of Paros and Mimnermos of Colophon, living in the $7^{\text {th }}$ century B.C. Ardys captured Priene and attacked Miletus. After having defeated the Cimmerians, Alyattes and his successor had a strong interest in the Ionian cities; capturing Smyrna, Priene and Klazomenai. Thereafter, Croesus attacked Ephesus and brought the Greeks into tributary status toward him, and his territory expanded in all directions (Kerschner, 2010; Köse, 2012). Herein, the majority sites of western Anatolia in Aeolia and Ionia were dominated by Lydians (Map 2), who were the world's first merchant according to Herodotus (Y1ldırım and Oban, 2011; Baughan, 2014).

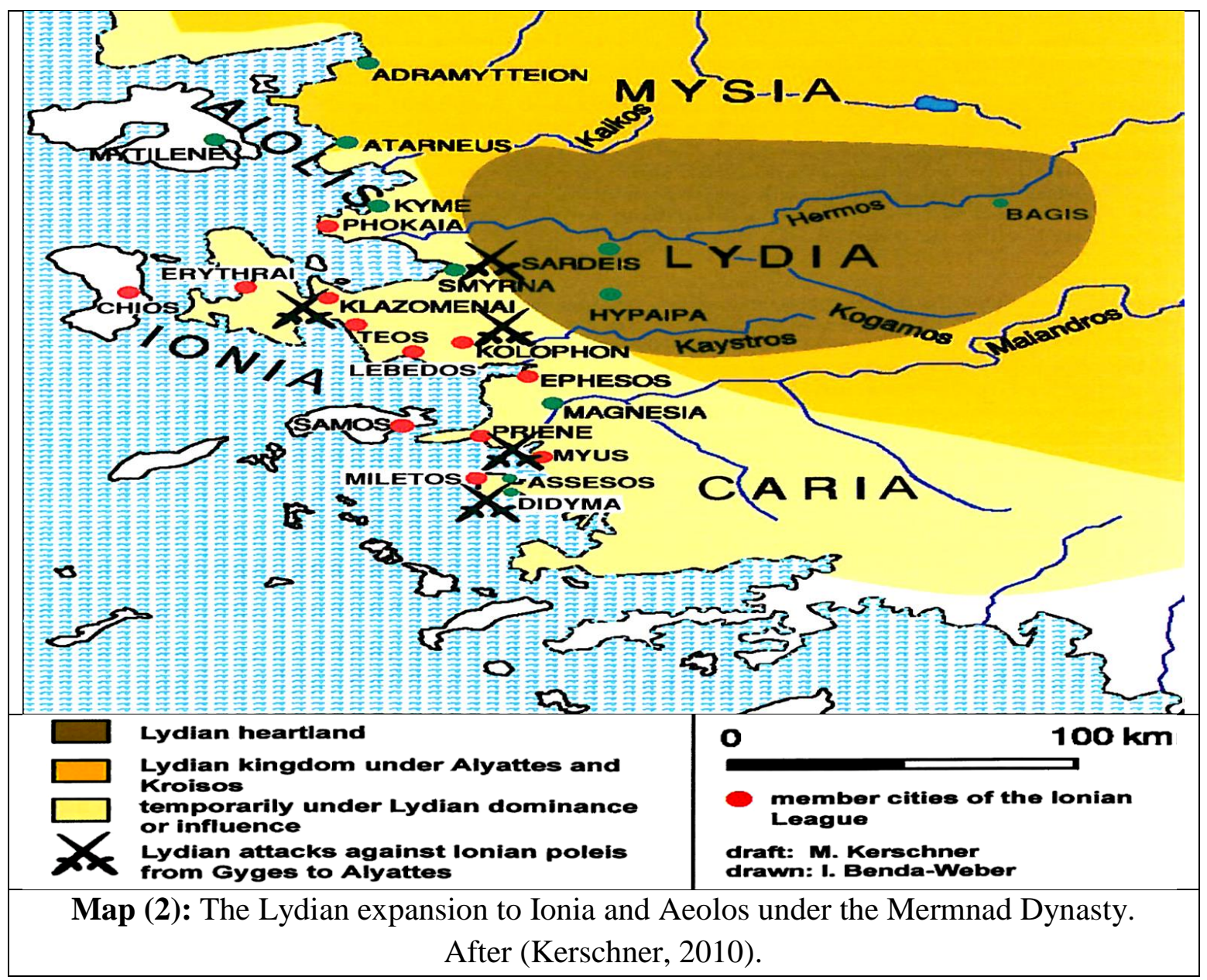

The Lydian politics of the Mermnads did not restrict to military raids, but also inclined to have diverse strategies by the marriage alliances in order to win and secure more influence in Ionia and Aeolis (Kerschner, 2010). These seem to have been a defining feature and a royal tradition between Lydians and other western Anatolian cultures; so they regularly chose their consorts, or gave their daughters to, the patrician families of Ionia (Perrot, 2013). It is recorded that both of Carian 
and Ionian wives bore children to Alyattes; who sealed a marriage alliance with Ephesus by marrying his daughter to the Ephesian tyrant, Melas, whose successor and son, Pindaros, was overthrown. Also, Croesus, whose mother was Alyattes' Carian wife, had an Ionian half-brother and both of the Ephesian and Median brothers-in-law. This trend extends back further to Gyges, whose mother was said to be Phrygian, while his wife was Mysian (Roosevelt, 2012).

In addition, the Mermnads seem to have interposed between the townships of seaboard and populations located on the Central plateau, so they tried to exert influence even on offshore islands during civil strife by offering financial support to political factions, as the group led by the poet Alkaios of Mytilene on Lesbos. Also, bribery as means of politics was used by Alyattes against the Colophonians. Their proverbial wealth enabled to offer tempting sums (Kerschner, 2010). Thus, the Lydian rule was based on cultural benefits and sharing trade.

In the spheres of religious practice and artistic production, strong ties with the Greek cultures were notable. The Lydian dedications in Ionian sanctuaries became a pleasant tradition; including vessels, statues, and bricks made of silver and gold. Apparently all of Gyges, Alyattes and Croesus donated lavish votives in Greek sanctuaries, most often to Apollo at Delphi, whose oracle loomed large at critical points of their lives. It gave its blessing to Gyges' usurpation of the throne, and when Croesus asked if he should attack the Persian Empire, it predicted the unfortunate war against Cyrus, and the way out of illness. Croesus' dedications in Ionian sanctuaries have been appeared at Didyma (Kerschner, 2010). Also, the temple of Artemis at Ephesus was finished with the help of Croesus (Hero. 1:13, $19,53,92)$, whose name is inscribed in its front column, as "Preserved by King Croesus". Unlike Miletus, Ephesus and Smyrna show a noticeable frequency of Lydian and Lydianizing votive. Also, Artemis of Ephesus had owned a branch sanctuary at Sardis, which an Ephesian delegation visited in annual procession in order to offer chitons to the goddess (Kerschner, 2010; Hanfmann, 1978).

\section{The Artificial Spots of the Lydo-Greek Interactions}

The Lydians and East Greeks always had economic and cultural exchange. The early roads from central and southern Anatolia to the Aegean coast encouraged the commercial activities in the Aegean towns, such as Sardis and Manisa (Magnesia). Lydia became an important cultural center in the Eastern Mediterranean, definitely after its subjection of the western half of Anatolia under the reign of Alyattes and 
his son Croesus, thereby facilitating commerce. The trade routes from Ionia to the central plateau through the long river valleys of Hermos and Meandrous gained in importance. The amount of Greek imports at Sardis is noticeable from the second half of the $8^{\text {th }}$ century B.C. (Yildırım and Oban, 2011). The Ionians were pioneer of a movement overseas through their merchants and mercenaries who revived contact with Levant and Egypt, carrying back the cultural elements from the Near East, apparently the alphabet, sculpture, buildings, and iron technology. They influenced the Hellenic world and the hinterlands of Anatolia, as well their sculptors created the first masterpieces of freestanding sculpture. Similarly, the Lydian kings invited all of Greek artists, merchants, and soldiers to their court at Sardis; also they patronized Delphi and Didyma (Harl, 2001; Kerschner, 2010).

The wide spread of the Phrygian splendid bronzes made in Lydia and Ionia during the $7^{\text {th }}$ century B.C. might have been explained by the immigrations of Phrygian artists, from whom both Lydia and Ionia adopted and modified models. Thus, Lydia has a prominent role as an intermediary of the Phrygian metalwork skills which must have been in demand in the west. Not only did the Lydians introduce money to Greek, they made an impact on artistic developments; to be as a bridge for adopted and adapted elements of the Phrygian art, and their own art influenced western Anatolia. Thus, they played a main role in the formation of the Greek art in Anatolia, like artists from Phrygia and Ionia (Köse, 2012). Therefore, the cultural contacts between Lydia and Ionia were frequent; and most aspects of the Lydian culture had been heavily influenced by Ionia, while the Near Eastern influence on Lydia was minimal (van Dongen, 2007).

In the light of the neighboring of Lydians and East Greeks, their interrelations and contacts were mostly numerous and manifold. This affinity is emphasized by the East Greek accounts; in which Herodotus (1.94) documented that the Lydian customs are close to those of the Greek; and the Greek poets of the Archaic Period perceived the Mermnad dynast as the model of wealth, power, and luxury. Also, the Greek tyrants, who seized power in many poleis during the $7^{\text {th }}-6^{\text {th }}$ centuries B.C., emulated the Lydian monarchs (Kerschner, 2010).

Archaeologically, many aspects of the Lydian culture combines the traditions of Anatolia and Greek; in which the Anatolian are the tumulus and rock-cut chamber tombs, some pottery shapes, notably the lydion unguent container, and decorative varieties of bichrome and black-on-red wares, and the highly marbling. In turn, these Greek elements could be traced in the architectural ornament, including the 
terracotta roof and revetment tiles, and the Ionic repertory of column design, moldings, individual motifs; sculptural motifs, design, and the style of kouroi and lions; pottery vessel forms such as crater and skyphos; besides the alphabetic writing system with certain changes (Greenewalt, 1997). In general, the following study aims to focus on examples of the cultural aspects which manifested for both sides; also pursuing certain of the early Greek artistic elements which have been found in Anatolia, as follows:

\subsection{The Bordered Places of the Lydo-Greek Relationships:}

The close relationships between the Greek art and the western Anatolian sites in the Archaic Period have been supported by large numbers of excavations and the textual sources. In this way, it is necessary to highlight the most prominent sites which witness to this artistic-architecture mixture:

5.1.1. Smyrna (modern Izmir): This city is a great emporium at central point on the Aegean coast and partly built upon the side of a lofty hill. About 1050/950 B.C., it was occupied about by Greek immigrants of Aeolians who lived in oval thatched houses, then took much of place to be believed that they expelled the preGreek inhabitants. It preserved a monumental Aeolic temple for goddess Athena, and most of its superstructure reconstructed during the sack of the city by Alyattes, which is of the greatest importance for understanding the emergence of East Greek architecture (Cook and Nicholls, 1998). The overviews of the political, economic, cultural, and religious relations between the Lydians and Ionians have shown that Ephesus and Smyrna, both cloth neighbors of Sardis, had more intensive links with Lydia than the other Ionian poleis. Also, the Lydian language was spoken and understood by a part of the inhabitations in these two cities (Kerschner, 2010). In addition, the intermarriages between Lydian royals and lords of Ephesus down to the time of Croesus indicate that by the late of the $7^{\text {th }}$ century B.C, Ephesus was already a half-Lydian trading outlet on the coast (Şare, 2010).

5.1.2. Miletus: It is the southernmost of Ionian cities and the mother city of many colonies in Propontis (modern the Marmara Sea) and Pontus (modern the Black Sea); located on a hillside surrounded by large ports at the mouth of the Maeander River, $15 \mathrm{~km}$. away from Priene, therefore it was frequent attacked by all of the Mermnad kings (Kerschner, 2010). Several accounts name this city as a center of textile production, and its harbor as famous for textile export to the Mediterranean (Şare, 2011). Its excavations have revealed both of the Minoan and Mycenaean 
objects, whereas it was a cultural and economic center of the east Greece cities under the Lydian rule (Fontenrose, 1988; Harl, 2001).

5.1.3. Assos (Behramkale): This site is located on the coast of Adramytteion Gulf, southern Troad (Troas, modern Biga peninsula). It was one of the Aeolian colonies (Serdaroğlu, 1990); including a unique archaic temple of Athena, about 530 B.C. It was built of andesite and combined Doric and Ionic elements. Its decorations are showing mythological themes of Heracles centaurs and sphinxes, also hunting scenes of different animals, as panthers and bulls (Köse, 2012; Jenkins, 2006).

5.1.4. Neandreia: It was a Greek city in the Troad area, on the slopes of Çğrı Mt. that is located in the south-west of Ezine district of Çanakkale province. It was founded as a Greek colony by Aeolian settlers, about 700 B.C.; including a temple with a rectangular cella divided in the middle by a row of internal columns and was surrounded by another columnar portico in peripteral plan, similar to a temple in Larissa (Köse, 2012).

5.1.5. Assesos (modern Mengerevtepe): It is a small Greek town in the region of Caria, some $7 \mathrm{~km}$ south-east of Miletus, and the site of Athena Sanctuary. It was discovered in 1992, after the discovery of an ashy layer dating to the $7^{\text {th }}$ century B.C., at the northeast plateau, where it is situated. Before the reign of Croesus, the Lydian did not succeed in conquering Miletus and their efforts to siege this city seem to be futile. In the Alyattes' war against the Milesians, a fire set by Lydian soldiers burnt the temple of Athena in the Milesian town of Assesos (Hero. 1. 1722). This brought an illness upon king. In fulfillment of an order of Apollo at Delphi, he erected two temples for Athena and subsequently recovered his health. Any rate, Alyattes and the tyrant of Miletus, Thrasybulus, concluded a treaty for friendship (Kerschner, 2010).

\subsection{The Outlines of the Greek Architecture Impact within Anatolia:}

The Anatolian kingdoms of Phrygia, Lydia and Lycia, which are bordered by the Greek colonies, may have been influenced by the Greek architectural remains. There are three main types of orders -Doric, Ionic, and Corinthian in the classical architecture, which were added by the Greek migrations to be fixed in many sites of western Anatolia and later adopted by the Romans (Fig. 1). Although all these orders were developed from the natural elements and both Doric and Ionic orders are definitely originated in the wooden architecture and seem to have appeared at 
the same time, they are differed from each other either of column structure (height, thickness and capitals, the positioning of roofs, decorations and bases) and the entablature resting upon it (Köse, 2012). Thus, we would just deal with the two older orders which concurrent with the study as follows:

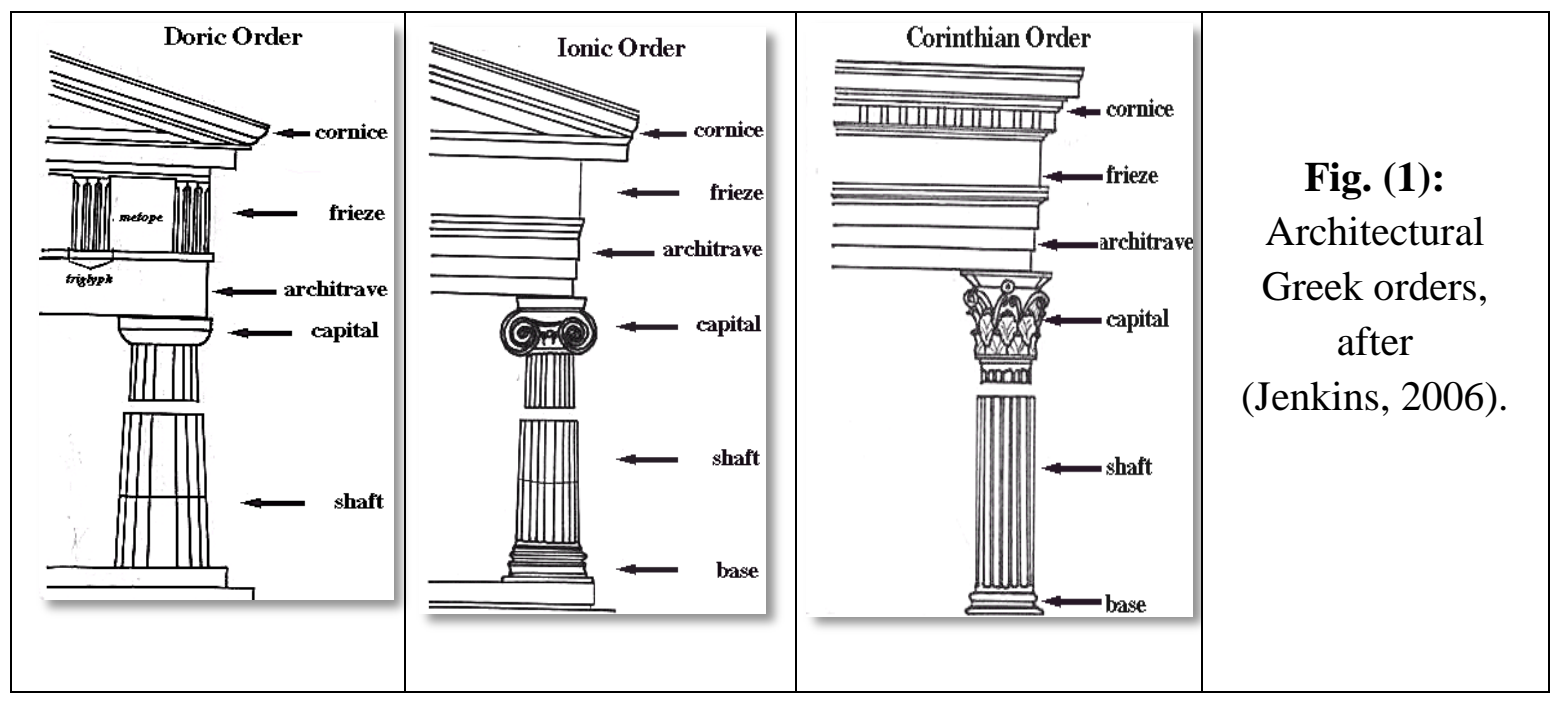

5.2.1. The Doric order: This order could be originated on the western Greece by the $7^{\text {th }}$ century B.C., to be mostly the simplest and oldest construction; in which the column rested on the platform without base, but its bottom is thick to be very powerful on the buildings (Palagia, 2012). In addition, it is of short, heavy fluted columns with a simple round capital of which a convex tapering neck, so- called echinus, topped by a square block, so-called abacus, connecting the capital to the entablature divided into three horizontal registers, to appear plain but powerful, and its shaft channeled with twenty concave flutes. The temple of Athena of Assus is the best example of the Doric order in Anatolia; also this order has been adopted in several places, for instance the temples of Apollo at Delphi, the Olympian Zeus at Agrigento, Italy, and Zeus at Cyrene, Libya (Robert 1992; Harl, 2001).

5.2.2. The Ionic order: It is taller than Doric order, with more delicate decoration of the column's capital and other decorative elements. Its column is distinguished by slender, fluted pillars with a large base looking like a set of stacked rings, and two opposed volutes in the echinus of the capital of which 20:40 flutes that are separated by a flat band as a fillet. Almost 600 B.C., this order was developed in East Greek cities along the western Anatolian coast and southern Italy, to become the favorite style of Greek cities like Ionia and the Aegean islands, even utilized in erection of almost buildings, such as the sanctuary of Delphi around 525 B.C. (Jenkins, 2006), the temple of Artemis at Ephesus, Hera at 
Samos, and Dionysus at Teos (Sığacik) on the Ionian coast which resembles the temple of Athena in Priene, ca. 340 B.C. (Webb, 1996; Harl, 2001). Worthy of note that the Aeolians architecture may have been owed to the Ionian architecture in Anatolia, whereas its columns is strong similarity to Ionic columns, particularly in rich floral and vegetable decoration (Betancourt, 1977); save for its capital which has a palmette thrusting up between two carved spirals or springing volutes from a common stem. Although the Aeolic order fell out of use at the end of Archaic Period in Greek, its capitals became widespread usage by other Aeolian cities, as Aigai, Larissa, and Neandreia (Köse, 2012; Waldman and Mason, 2006).

\subsection{The Archaic Greek Sculpture:}

The sculpture was one of the most important forms of artistic expression to depict the development of Greek art from the earliest historical times. The first impulse behind Greek sculptures was religious; in which they were used as votive offerings in sanctuaries, and cult statues, besides the decoration of public and private spaces. The archaic period witnessed the early votive art in the form of marble figures of youths and girls, often over life-sized, which were dedicated in major sanctuaries as gifts to the divinity (Ridgway, 1971; Damaskos, 2012). The East Greek style of sculpture can be confined to the standing figure of kouros ( $\mathrm{pl}$. kouroi, nude males) and its counterpart of kore (pl. korai, draped females) that appeared about 660 B.C. and remained to the end of archaic period in ca. 500 B.C. This style is mostly represented by major examples at the East Greek sanctuaries of Samos, Didyma, Miletos, Smyrna, and Sardis (Fig. 2). Also, the Athenian korai were products of the Ionian masters or inspired by the Ionian schools (Harl, 2001; Hanfmann, 1978).

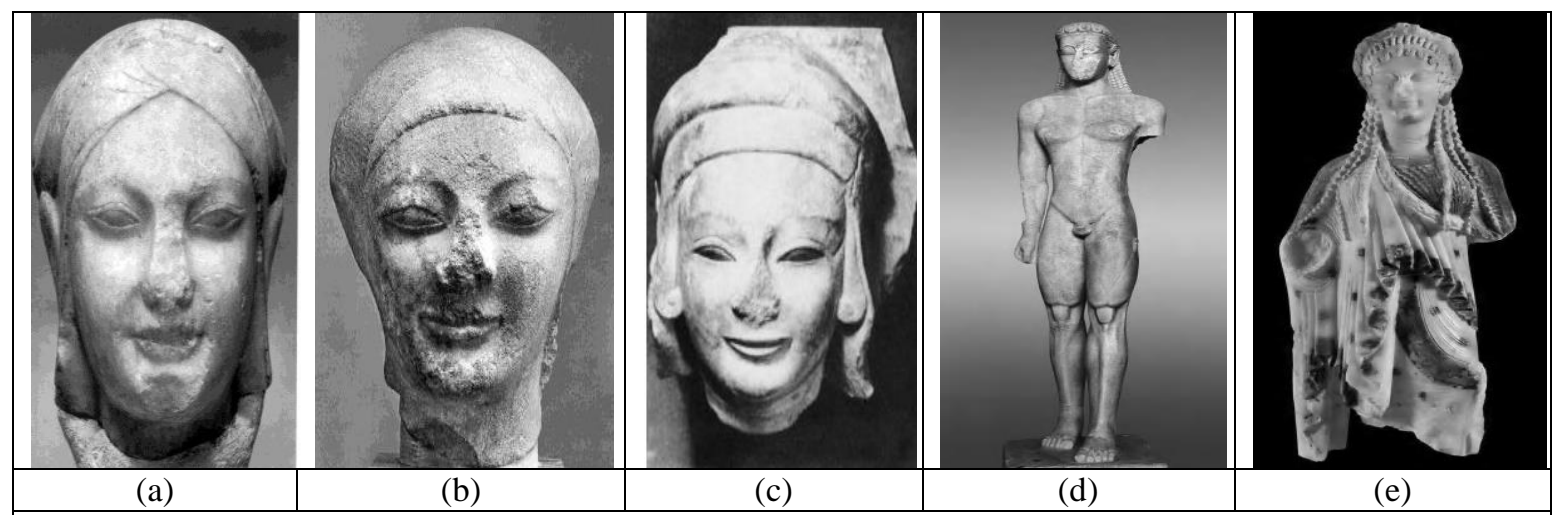

Fig. (2): Examples of the East Greek sculptures; in which (a) Kore head from the Athena Temple at Smyrna with Samian style headband-veil, 540 B.C., Izmir Museum, inv. no. 15136. (b-c) Two kore heads with a bonnet veil from Miletos (ca. 540 B.C.), and other 
head wearing a lappet-style veil from the column drum of the Apollo Temple at Didyma (ca. 520 B.C.), Berlin Staatliche Antikensammlungen. (d-e) Types of the Archaic marble Greek sculptures, preserved in Athens; including: a statue of a youth (kouros), ca. 600 B.C., National Archaeo-logical Museum, no. 2720; and a statue of maiden (kore). ca. 510 B.C., Acropolis Museum, no. 675. After (Şare, 2011; Köse, 2012; Damaskos, 2012).

The natural treatment of forms was the defining characteristic of the East Greek sculptural styles in the archaic period that witnessed the beginning of votive art in the form of marble figures. They were dedicated in the major sanctuaries as gifts to the divinity. In this context, we can introduce some of the Greek elements of sculptural groups which were diffused into bordered places, as follows:

5.3.1. The Geneleos Group: This monument could be the typical example for the early implications of the East Greek sculptural style in archaic Ionian sanctuaries. It was discovered during the German excavations in the southern region of Samos, about 1911-1912 (Freyer-Schauenburg, 1974), where an entire family of reclining banqueters occupied a long and narrow two-stepped base flanking Sacred Street, leading to the temple of Hera, Heraion. As for Geneleos, whose name is erected on a monument here, he was a sculptor of the Samos workshop (Baughan, 2011). It consisted of a single, two stepped, and long base with six approximately life-size marble figures on top (Fig. 3); in which about four centrally positioned standing figures framed by one seated of an enthroned woman and one reclining figure. Its identification could represent a family enjoying a cult banquet, consisting of the enthroned lady (mother) to left, the father reclining at a cult meal, their children standing in between, closing by a draped youth with aulos and three korai of daughters wear all of tunic, mantle (i.e. himation) and a veil for a ritual dance (Köse, 2012). Thus, its identification could represent a family group taking part in a banquet or more realist as a group of priestesses, relating to its position (Erin Black, 1998).

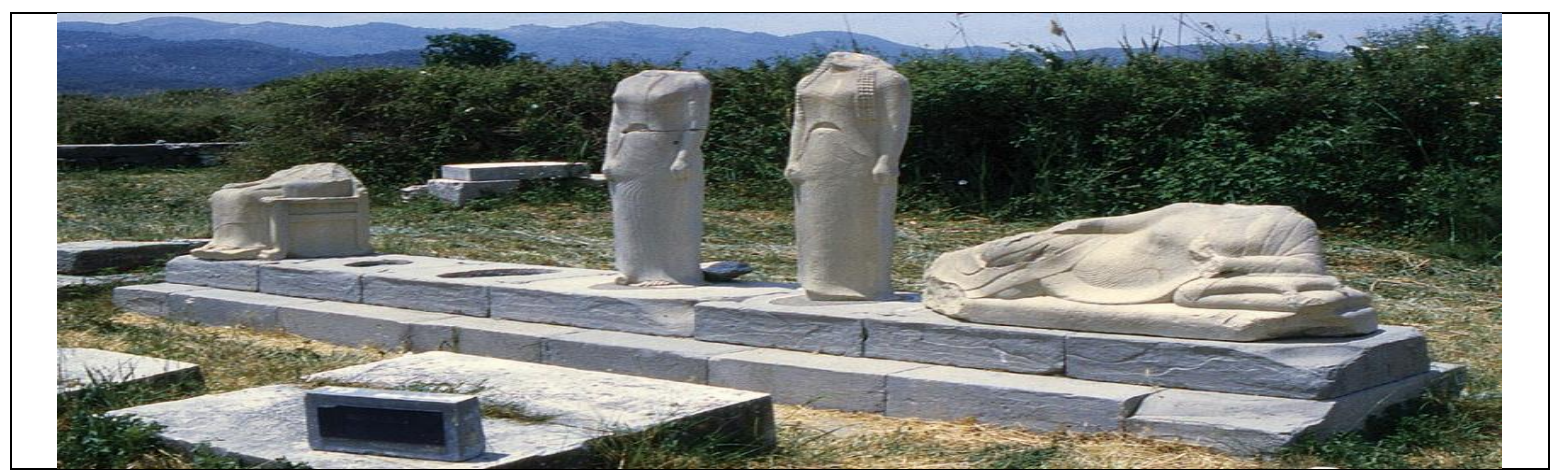




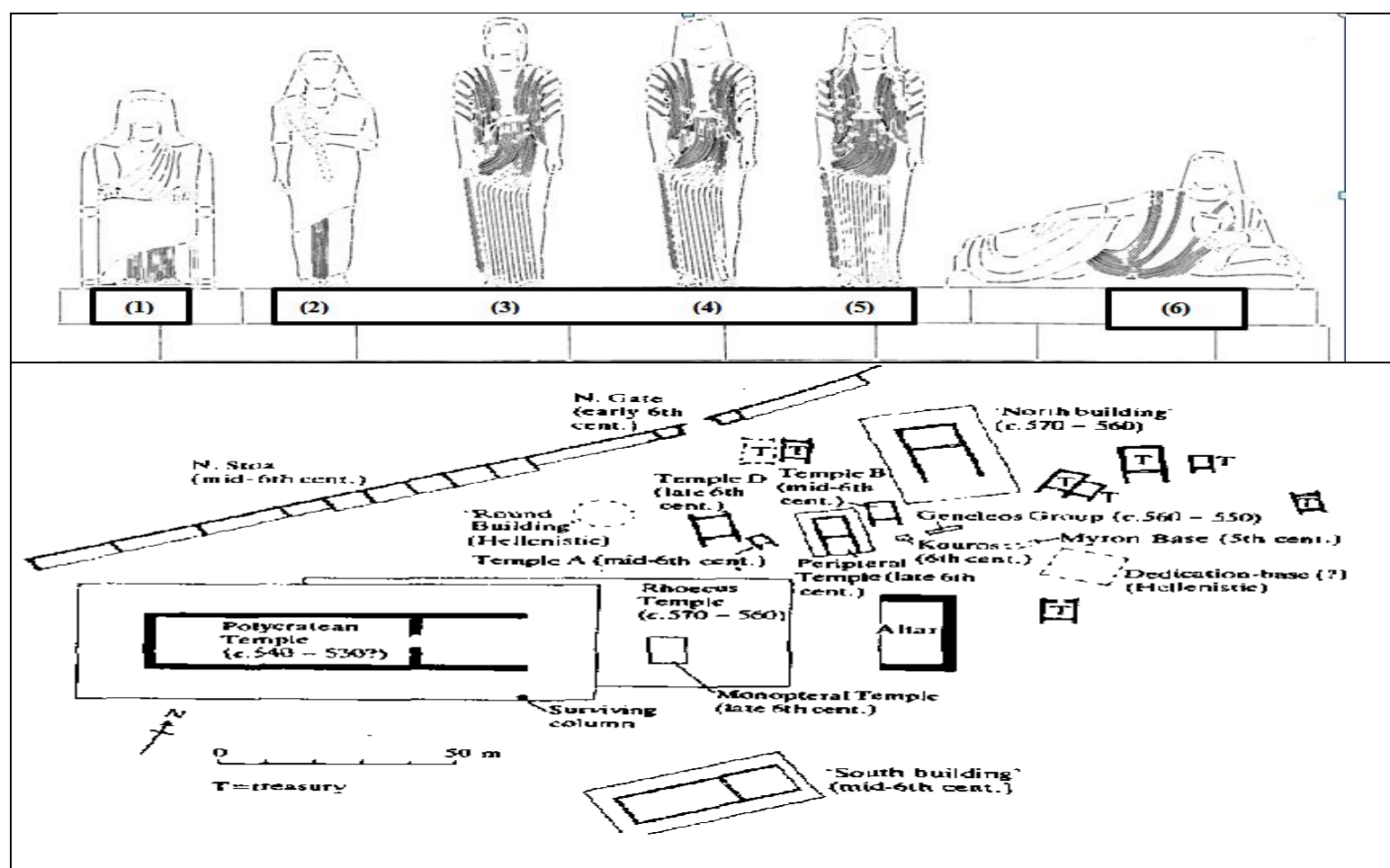

Fig. (3) The figures of Geneleos Group, drawing of its reconstruction; besides the plan of the Heraion of Samos; after (Erin Black 1998; Baughan 2011).

5.3.3. The Cheramyes Kore: This statue is one of the earliest representations of kore, robed young girl, which represented the East Greek artistic interest in soft, fleshy forms as compared to rigid, linear forms seen in earlier examples of kouroi and korai from the Greek mainland. It was discovered in 1875, on the Sacred Way; near Heraion of Samos (Fig. 4). An inscription runs along the veil edge, describing it as part of a statuary group offered by an Ionian aristocrat, Cheramyes, to the goddess Hera and its temple. This figure has been dressed in three items of traditional Ionian clothing: a light, finely-pleated linen tunic, a thick woolen cloak or mantle draped like a sash around the bust and its head, which is unfortunately missed, may have been covered by a tightly fitting veil clearly rendered the ears (Şare, 2011). Thus, the korai by Cheramyes are dressed in the same way, but they hold a bird or a key against their breast in left hand, which could be a clue to the statue's religious purpose, and perhaps to the role of the female servants of the cult of Hera, whom the figures represent (Köse, 2012). 


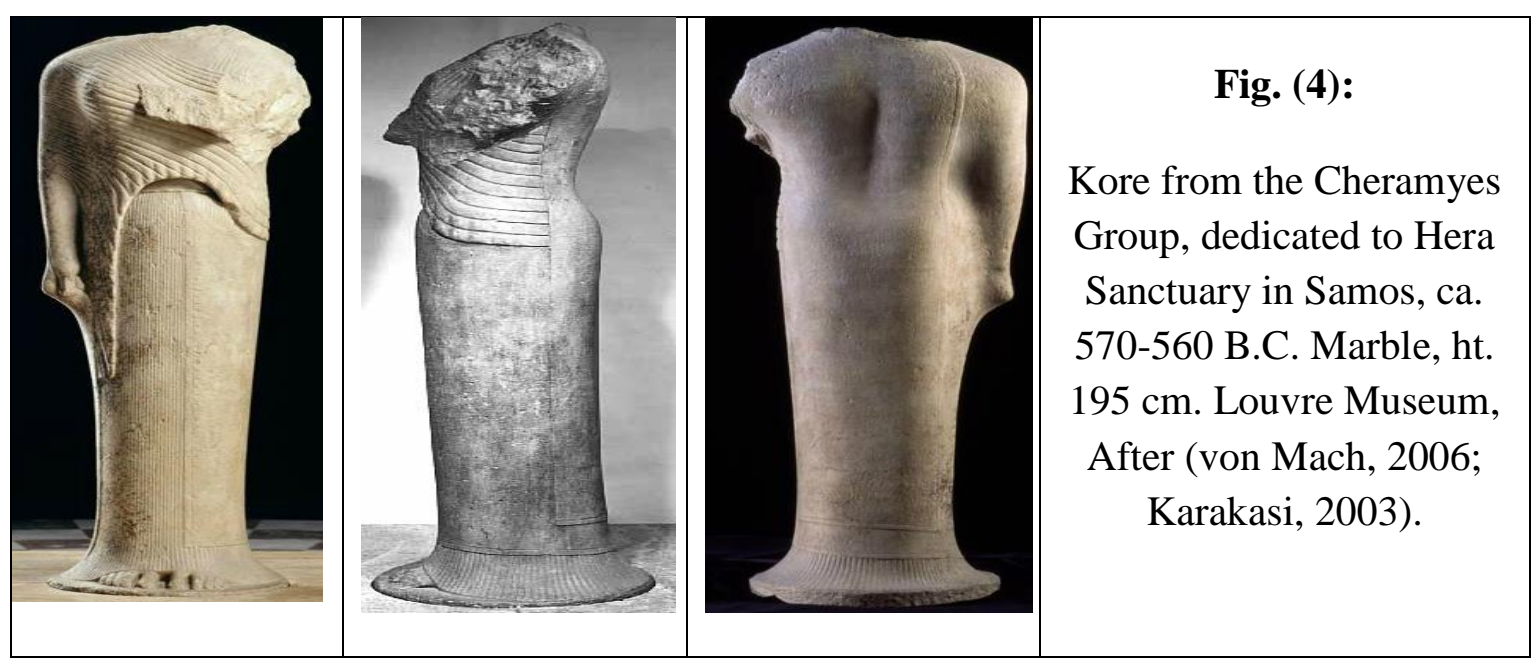

\section{Reference:}

- Baughan, E.P., 2011, "Sculpted Symposiasts of Ionia," American Journal Archaeology, vol. 115/ 1: 19-53.

- ------, 2014, "Lydia, Archaeology of," in: Encyclopedia of Global Archaeology, New York: 4566-574.

- Betancourt, P., 1977, The Aeolic Style in Architecture, Princeton.

- Bryce, T., 1999, "Anatolian Scribes in Mycenaean Greece," Historia: Zeitschrift für Alte Geschichte, vol. 48/ 3: 257-64.

- Cook, J.M. and R.V. Nicholls, 1998, Old Smyrna Excavations: The Temples of Athena, Supplementary, vol. 30, the British School at Athens.

- Damaskos, D., 2012, "Free-standing and Relief Sculpture," in: A Companion to Greek Art, vol. 1, Blackwell Publishing Ltd.: 105-131.

- Erin Black, B. A., 1998, Cult and Gender in the Geneleos Group, Master diss., McMaster University.

- Fontenrose, J., 1988, Didyma: Apollo's Oracle, Cult, and Companions, Berkeley and Los Angeles: University of California Press.

- Freyer-Schauenburg, B., 1974, Bildwerke der archaischen Zeit und des strengen Stils. Samos 11. Bonn: Rudolf Habelt.

- Greenewalt, C.H., Jr., 1997, "Sardis," in: The Oxford Encyclopedia of Archaeology in the Near East, vol. 4, Oxford \& New York: Oxford University Press: 484-88.

- Harl, K.W., 2001, Great Ancient Civilization of Asia Minor: Course Guidebook, Virginia: The Great Courses. 
- Hanfmann, G.M.A., 1978, "The Sculpture of the Prehistoric, Lydian, and Persian Periods," in: Sculpture from Sardis: The Finds through 1975, Harvard University Press: 13-28.

- Herodotus, 2014, The History of Herodotus, vol. 1, tr. G. Rawlinson, The University of Adelaide Library. After: http://ebooks.adelaide.edu.au/h/herodotus/h4/index.html.

- Jenkins, I., 2006, Greek Architecture and Its Sculpture, Harvard University Press.

- Karakasi, K., 2003, Archaic Korai, Los Angeles.

- Kerschner, M., 2010, "The Lydians and their Ionian and Aiolian Neighbours/ Lidyalıların Komşuları İyonyalılar ve Aiola'lılar," in: Lidyalılar ve Dünyalar1/The Lydians and their World, İstanbul: 247-65.

- Köse, V., 2012, "Asia Minor," in: A Companion to Greek Art, WileyBlackwell: 330-49.

- Liverani, M., 2014, The Ancient Near East: History, Society and Economy, Routledge.

- Markot, R., 1996, The Penguin Historical Atlas of Ancient Greece, England: Penguin Books.

- Özgen, İ., 1985, A Study of Anatolian and East Greek Costume in the Iron Age, Ph.D., diss., University Microfilms International.

- Palagia, O., 2012, "Architectural Sculpture," in: A Companion to Greek Art, Wiley-Blackwell: 155-70.

- Perrot, G., 2013, History of Art in Phrygia, Lydia, Caria, and Lycia. London. After: www. ForgottenBooks.org.

- Ridgway, B.S., 1971, “The Setting of Greek Sculpture," Hesperia, vol. 40/ 3: 336-56.

- Robert, A., 1992, Classical Architecture: A Complete Handbook. London: Penguin.

- Roosevelt, C.H., 2012: "Iron Age Western Anatolia: The Lydian Empire and Dynastic Lycia," in: A Companion to the Archaeology of the Ancient Near East, vol. 2, Wiley-Blackwell: 896-913.

- Solano, A., 2015, From the Aegean to the ANE: Evidence of Greek Influence in the Ancient Near East Prior to the Time of Alexander the Great, Old Testament Introduction.

- Şare, T., 2010, "An Archaic Ivory Figurine from a Tumulus near Elmali: Cultural Hybrid-ization and a New Anatolian Style," Hesperia: The Journal of the American School of Classical Studies at Athens, vol. 79/1:53-78.

------, 2011, Dress and Identity in the Arts of Western Anatolia: the Seventh through Fourth Centuries BCE, Ph.D. diss., New Brunswick, New Jersey. 
- Serdaroğlu, Ü., 1990, "Zur Geschichte der Stadt Assos und ihrer Ausgrabungen," in: Ausgrabungen in Assos (Asia Minor Studien, Band 2). Bonn: 1-6.

- Thomas, C., 1978, "Found: the Dorians: Archeology and Greek linguistics at the end of the Late Bronze Age," Expedition Magazine, Penn Museum, vol. 20/3: 21-25. Available online at: https://www.penn.museum/sites/expedition/found-the-dorians/.

- van Dongen, E., 2007, "Contacts between pre-classical Greece and the Near East in the Context of Cultural Influences: An overview," Studien zur antiken Weltgeschichte, vol. 2: 13-49. Available online at: www.verlagantike.de.

- --------, 2008, "The Study of Near Eastern Influences on Greece: towards the Point," KASKAL: Rivista di storia, ambienti e culture del Vicino Oriente Antico, vol. 5: 233-50.

- ---------, 2013, "The Overland Route: Intra-Anatolia Interaction ca. 1000$540 \mathrm{BC}$ and the Transmission of the Alphabet," Ancient West \& East, vol. 12: 47-70.

- von Mach, E., 2006, Greek Sculpture: Its spirit and Its Principles, New York: Parkstone Press International.

- Waldman, C. and C. Mason, 2006, Encyclopedia of Europeans Peoples, New York: Facts on File.

- Waugh, N., 2012, "Chronology and Topography," in: A Companion to Greek Art, Wiley-Blackwell: 17-38.

- Webb, P.A., 1966, Hellenistic Architectural Sculpture: Figural Motifs in Western Anatolia and the Aegean Islands, London: The University of Wisconsin Press.

- Yildirim R. and R. Oban, 2011, "The Importance of Heritage Roads on the Development of Western Anatolia and Izmir," within the 2nd International Geography Symposium- Mediterranean Environment, Procedia Social and Behavioral Sciences, vol. 19: 90-97. 